\title{
THE USE OF PROBIOTIC AND PROTEASE ENZYME IN LAYERS
}

\author{
ALI M. ALI ${ }^{1}$; MAI O. NADA ${ }^{1}$; THABET M.G. ${ }^{2}$ and SABRY E.O. ${ }^{3}$ \\ ${ }^{1}$ : Diseases Dept., Animal Health Research Institute, Benha-Branch (Biochemistry, Toxicology and Nutritional \\ Deficiency \\ 2: Food Control Dept., Animal Health Research Institute, Benha-Branch (Biochemistry, Toxicology and \\ Nutritional Deficiency \\ ${ }^{3}$ : Avian Diseases Dept., Animal Health Research Institute, Benha-Branch (Biochemistry, Toxicology and \\ Nutritional Deficiency
}

Received: 21 November 2016;

Accepted: 30 January 2017

\begin{abstract}
The present work was conducted to evaluate the effect of concurrent use of probiotic and protease enzyme in commercial layers fed ration with either normal or low crude protein content. One hundred and twenty, 40week-old apparently healthy Lohman commercial laying chickens were used. Birds were divided into six equal groups (20 each). Group 1 was fed a balanced ration only and kept as control group. Group 2 was fed the balanced ration mixed with a protease enzyme $(0.5 \mathrm{~kg} / \mathrm{ton}$ feed $)$. Group 3 was fed ration with crude protein $15.73 \%$ and mixed with a protease enzyme $(0.5 \mathrm{~kg} / \mathrm{ton}$ feed). Group 4 was fed the balanced ration mixed with a probiotic $(0.5 \mathrm{~kg} /$ ton feed). Group 5 was fed the balanced ration mixed with a combination of protease enzyme $(0.5 \mathrm{~kg} /$ ton feed $)$ and probiotic $(0.5 \mathrm{~kg} /$ ton feed). Group 6 was fed a ration with crude protein $15.73 \%$ and mixed with a combination of protease enzyme $(0.5 \mathrm{~kg} / \mathrm{ton}$ feed $)$ and probiotic $(0.5 \mathrm{~kg} / \mathrm{ton}$ feed $)$. The experimental period was five successive weeks (from 40 to 45-week-old). Groups 2, 4, 5 and 6 showed a significant increase of production parameters (egg laying rate, average egg weight and feed conversion per eggs), serum total protein, albumin and globulin when compared with control group. Probiotic treated groups $(4,5$ and 6$)$ showed a significant improvement in serum lipid profile and carcass quality parameters. It could be concluded that the combination of protease and probiotic allows poultry producers to use feeds formulated with protein and amino acids that are $7.5 \%$ lower than the recommended industrial standards. This combination not only with no sacrifice in bird performance but also with higher quantity and quality performance. Therefore, this combination is a potential to increase the producers profit.
\end{abstract}

Key words: Probiotic, Protease, Enzyme, Layers.

\section{INTRODUCTION}

Feed additives are products used in animal nutrition for improving the quality of feed and to improve the animal performance and health such as probiotic and protease enzyme.

Probiotic is a live microbial feed supplement which beneficially affects the host animal by improving its intestinal microbial balance (Fuller, 1992). According to Commission of the European Communities (2003), probiotic is an example of zootechnical, gut-flora stabilizer feed additives. Probiotics help improving digestion, nutrient metabolism and utilization of nutrients by offering digestible proteins, vitamins, enzymes and other

Corresponding author: Dr. ALI M. ALI

E-mail address: alimohamedphd@gmail.com

Present address: Diseases Dept., Animal Health Research Institute, Benha-Branch (Biochemistry, Toxicology and Nutritional Deficiency. important co-factors and by decreasing gut $\mathrm{pH}$ by production of lactic acids.

Probiotic as 'live enzyme factory' (amylase, protease, lipase) enhances digestion and absorption of carbohydrates, proteins and fats, which also increases the feed conversion efficiency. Probiotics help in metabolism of minerals and synthesis of vitamins (Biotin, Vitamin-B1, B2, B12 and K) which are responsible for proper growth and metabolism (Dhama and Singh, 2010). The facultative anaerobes (Bifidobacterium and Lactobacillus) included in probiotic bacterial consortium reduce the redox potential in the gut and render the environment suitable for obligate anaerobes (Chichlowski et al., 2007). An increase in the digestibility of dry matter is closely related to enzymes released by yeast (Lee et al., 2007). In poultry, probiotics improve growth performance (Awad et al., 2009), increase feed conversion efficiency (Saadia and Soliman, 2010) and improve immune responses (Bansal et al., 2011). 
Protein feedstuffs are consistently increasing in cost, a trend that has been exacerbated in recent years. In parallel, increased public concerns regarding the environmental impact of animal agriculture has increased the need to reduce nutrients in the waste generated by food animal production. Addition of exogenous enzymes to chickens' feeds has gained increasing attention. The prospect of stimulating a better utilization of the diet has both economic and environmental aspects, because less feed is needed to produce a certain amount of meat and fewer nutrients end up in the litter.

Protease enzymes naturally occur in the digestive tracts of all animals, including poultry. These protease enzymes break down dietary proteins into their constituent components, peptides and amino acids; that are directly absorbed by the gut. These endogenous protease enzymes are not as effective as other proteases in breaking down certain protein sources. Crude protein and amino acid digestibility reported for poultry indicate that valuable amounts of protein pass through the gastro-intestinal tract (GIT) without being completely digested (Lemme et al., 2004). This undigested protein represents an opportunity for the use of supplemental exogenous proteases in commercial layers feeds to improve protein digestibility. Protease enzymes increase protein digestibility by hydrolysis of storage and structural proteins and disrupts interactions of proteins with starch and fiber in the diet (Cowieson and Adeola, 2005). Furthermore, it targets other antinutritional factors in the diet as residual trypsin inhibitors (Caine et al., 1998) and lectins in soybean meal and some other vegetable proteins improving nutrient digestibility (Yu et al., 2007).

The present study was conducted to evaluate the effect of concurrent use of probiotic and protease enzyme in commercial layers fed ration with either normal or low crude protein content. Some production parameters, some biochemical parameters and carcass meat quality were also determined.

\section{MATERIALS AND METHODS}

\section{1 - Birds}

One hundred and twenty, 40-week-old apparently healthy Lohman Brown-Classic layers were purchased from Al-Wadi Poultry Company. The birds were allocated in separate units of metal wirefloored battery for five successive weeks (from 4045-week-old).

\section{2 - Protease enzyme}

Protease enzyme was produced by Novus Int., USA under a commercial name of CIBENZA ${ }^{\circledR}$ DP100. The protease activity was not less than $600000 \mathrm{U} / \mathrm{g}$, where one protease unit $(\mathrm{U})$ is defined as an increase of 0.01 absorbance at A 410 for 15 minutes at $37^{\circ} \mathrm{C}$ to hydrolyze azo-casein. It was added to ration at a dose of $0.5 \mathrm{~kg} / \mathrm{ton}$ feed for five successive weeks, according to the producer.

\section{3 - Probiotic}

Probiotic was produced by Angle Yeast Company, China under a commercial name of "Active Feed Dry Yeast". It contains Saccharomyces cerevisiae 20 billion CFU/g. It was added to ration at a dose of 0.5 $\mathrm{kg} / \mathrm{ton}$ feed for five successive weeks, according to the producer.

\section{4 - Experimental design}

One hundred and twenty, 40-week-old apparently healthy Lohman commercial laying chickens were used. They were divided into six equal groups of 20 chickens each. Group 1 was fed a balanced ration only and kept as control group. Group 2 was fed a balanced ration mixed with a protease enzyme at a dose of $0.5 \mathrm{~kg} /$ ton feed. Group 3 was fed ration with crude protein $15.73 \%$ [less than normal level $(17 \%)$ by $7.5 \%$ ] and mixed with a protease enzyme at a dose of $0.5 \mathrm{~kg} /$ ton feed. Group 4 was fed a balanced ration mixed with a probiotic at a dose of $0.5 \mathrm{~kg} / \mathrm{ton}$ feed. Group 5 was fed a balanced ration mixed with a combination of protease enzyme at a dose of 0.5 $\mathrm{kg} /$ ton feed and probiotic at a dose of $0.5 \mathrm{~kg} /$ ton feed. Group 6 was fed a ration with crude protein $15.73 \%$ and mixed with a combination of protease enzyme at a dose of $0.5 \mathrm{~kg} / \mathrm{ton}$ feed and probiotic at a dose of $0.5 \mathrm{~kg} / \mathrm{ton}$ feed. The chickens were fed these rations for five successive weeks (from 40 to 45 -week-old).

\section{5 - Production parameters}

Feed intake (FI) was obtained weekly as the ratio between the amount of feed consumed in each group and the number of birds in that group and recorded as grams/hen/day.

Average eggs production and eggs weight (g) were determined per each group for five successive weeks. The eggs production obtained by dividing the total eggs produced in each group by the number of chickens in that group. The result was recorded as percentage. The feed conversion per eggs (FCE) were calculated according to the following formula (Filho et al., 2015):

$\mathrm{FCE}=100 *(\mathrm{FI} /(\mathrm{ELR} * \mathrm{AEW})$

where $\mathrm{ELR}=\mathrm{Egg}$ laying rate $(\%$ of egg

laying/hen/day); AEW=Average eggs weight (g).

\section{6 - Biochemical examinations}

Blood samples were collected from the jugular vein of five chickens per each group at the end of fifth week. The collected samples were allowed to separate the serum and kept at $-20^{\circ} \mathrm{C}$ for estimating the activity of serum alanine aminotransferase (ALT), aspartate aminotransferase (AST) (Varliy, 1974), total proteins (Domas, 1975), albumin (Doumas, 1971). The serum globulin was calculated by subtracting serum albumin from serum total protein. Serum uric acid (Haisman and Muller, 1977) 
and creatinine (Henry, 1974), serum total cholesterol (Flegg, 1973), Triglycerides (TG), High-density lipoprotein cholesterol (HDL-C) (Gordon et al., 1977), Low-density lipoprotein cholesterol (LDL-C) (Friedewald et al., 1972) were estimated. Very lowdensity lipoprotein cholesterol (VLDL-C) was calculated by dividing triglycerides value by 5 (Tietz, 1976). Low-density lipoprotein cholesterol (LDL-C) was calculated by the following equation: LDL-C = (Total cholesterol) - (HDL-C) - (VLDL-C) (Ashayerizadeh et al., 2009).

\section{7 - Carcass Studies}

At the termination of experiment, ten birds from each group were randomly selected and deprived of food but not water for 14 hours. They were slaughtered and eviscerated for organ weight determination and sensory analysis of chicken breast meat to evaluate the meat quality assessment. Weight of organs and various parts were taken and expressed as percentage of the final life weight of the birds (Odunsi et al., 2009). Chicken breast meat samples were steamed separately with $60 \mathrm{ml}$ of water to a temperature of $100^{\circ} \mathrm{C}$ for 10 minutes to produce cooked meat samples. Equal quantities of salt (that is $2.0 \mathrm{~g}$ of granulated iodated salt) were added to chicken breast meat samples to produce salted cooked breast meat. The temperature-time treatment was monitored using a digital cooking thermometer with probe and timer with $0^{\circ} \mathrm{C}$ to $200^{\circ} \mathrm{C}$ range. Cooked chicken breast meat samples were sliced into cubes of uniform sizes and served warm to 8 trained sensory panelists. The trained sensory panelist evaluated meat color intensity, juiciness, Tenderness, flavor and overall acceptability of meat.

The sensory qualities of the meat were evaluated with 7 points category scale (1-7) according to (Snedecor and Cochran, 1987).

\section{8 - Statistical analysis}

Statistical analyses were conducted with the Statistical Package for Social Science (SPSS Inc. Released, 2009) to determine if variables differed between groups, according to Snedecor and Cochran (1989). The Shapiro-Willk test was used to test the normal distribution of the data before statistical analysis was performed. Compare between means were conducted by one-way ANOVA and subsequent Duncan's multiple range test (Duncan, $1955)$. Probability values of less than $5 \%(\mathrm{P} \leq 0.05)$ were considered significant.

\section{RESULTS}

The production parameters in commercial layers showed that, there were no significant differences in feed intake among experimental groups. The birds fed ration with normal crude protein content $(17 \%)$ and treated with protease enzyme (group 2) and probiotic treated groups $(4,5$ and 6$)$ showed a significant $(\mathrm{P} \leq 0.05)$ increase of egg laying rate (89.85, 89.67, 91.21 and $89.92 \% /$ hen/day), average egg weight $(64.08,64.33,64.57$ and $64.13 \mathrm{~g})$ and feed conversion per eggs $(1.93,1.92,1.90$ and 1.93) when compared with the other groups. Birds fed ration low in crude protein content $(15.73 \%)$ and treated with protease enzyme only (group 3 ) showed no significant $(\mathrm{P}>0.05)$ difference of egg laying rate $(85.12 \% /$ hen/day), average egg weight $(62.10 \mathrm{~g})$ and feed conversion per eggs (2.13) when compared with control group as shown in table 2 .

The blood biochemical parameters in commercial layers showed that, there were no significant differences in ALT, AST, uric acid and creatinine among experimental groups. The birds fed ration with normal crude protein $(17 \%)$ and treated with protease (group 2), probiotic (group 4), probiotic and protease (group 5) and birds fed ration with low crude protein (15.73\%) (group 6) showed a significant $(\mathrm{P} \leq 0.05)$ increase of serum total protein $(6.78,6.71,7.41$ and $6.46 \mathrm{~g} / \mathrm{dl})$, albumin $(3.89,3.96$, 4.22 and $3.91 \mathrm{~g} / \mathrm{dl})$ and globulin $(2.89,2.75,3.19$ and $2.55 \mathrm{~g} / \mathrm{dl}$ ), respectively when compared with the control group. The birds fed ration low in crude protein content $(15.73 \%)$ and treated with protease enzyme (group 3) showed no significant $(\mathrm{P}>0.05)$ difference of serum total protein $(3.42 \mathrm{mg} / / \mathrm{dl})$, albumin $(2.08 \mathrm{mg} / \mathrm{dl})$ and globulin $(1.34 \mathrm{mg} / \mathrm{dl})$ when compared with the normal control group. Regarding the lipid profile, probiotic treated groups $(4,5$ and 6$)$ showed a significant $(P \leq 0.05)$ decrease of serum total cholesterol $(72.65,70.85$ and 73.43 $\mathrm{mg} / \mathrm{dl})$, TG (26.44, 23.36 and $27.11 \mathrm{mg} / \mathrm{dl})$, LDL-C $(20.99,22.43$ and $26.12 \mathrm{mg} / \mathrm{dl})$ and VLDL-C (5.29, 4.67 and $5.42 \mathrm{mg} / \mathrm{dl}$ ), respectively when compared with other groups. In contrast, these groups $(4,5$ and 6) showed a significant $(P \leq 0.05)$ increase of HDLC (46.37, 43.74 and $41.89 \mathrm{mg} / \mathrm{dl})$, respectively when compared with other groups. The protease treated groups (2 and 3) did not show any significant differences in lipid profile when compared with the control group as represented in table 3 .

Data of carcass criteria are presented in table 4 . The differences in the percentages of body organ weights (liver, heart, kidney, gizzard, and abdominal fat) were insignificant among all groups. The percentage weight of gizzard to body wright was $1.56 \pm 0.32$, $1.36 \pm 0.22, \quad 1.87 \pm 0.27, \quad 1.53 \pm 0.33, \quad 1.76 \pm 0.28$ and $1.64 \pm 0.26$ for group $1,2,3,4,5$ and 6 , respectively. The percentage weight of liver to body weight was $2.10 \pm 0.2,1.94 \pm 0.1,1.9 \pm 0.1,2.1 \pm 0.1,1.91 \pm 0.1$ and $2.15 \pm 0.1$ for group $1,2,3,4,5$ and 6 , respectively.

There were significant $(\mathrm{P} \leq 0.05)$ differences in the tenderness and overall acceptability of breast muscle (Tables 5). For tenderness, meat sample from groups 2,4 and 5 were moderately $(\mathrm{P} \leq 0.05)$ tender than those of groups 1,3 and 6 which were slightly tender. The mean values of tenderness for chicken 
meat were $4.89 \pm 0.26$ and $5.40 \pm 0.27$ for groups 1 and 3 , respectively. On the other hand, the mean values of tenderness for chicken meat were $5.63 \pm 0.30$, $5.45 \pm 0.32,5.42 \pm 0.26$ and $4.98 \pm 0.16$ for groups 2,4 , 5 and 6, respectively. Similarly, for overall acceptability parameter, breast muscle sample from groups 2, 4, 5 and 6 were significantly higher than samples that of groups 1 and3. The mean values of overall acceptability for chicken meat were 6.11 \pm 0.03 and $6.35 \pm 0.04$ for groups 1 and 3, respectively. Furthermore, the mean values of overall acceptability for chicken meat were $6.60 \pm 0.05,6.54$ $\pm 0.04,6.39 \pm 0.04$ and $6.22 \pm 0.03$ for groups $2,4,5$ and 6 , respectively.

Table 1: Composition and chemical analyses of experiment rations

\begin{tabular}{|c|c|c|c|c|c|c|}
\hline \multirow{2}{*}{ Ingredients } & \multicolumn{6}{|c|}{ Groups } \\
\hline & 1 & 2 & 3 & 4 & 5 & 6 \\
\hline Yellow corn & 73.44 & 73.44 & 76.73 & 73.44 & 73.44 & 76.73 \\
\hline Soya bean meal (46\%) & 15.54 & 15.54 & 14.21 & 15.54 & 15.54 & 14.21 \\
\hline Full-Fat soya $(35 \%)$ & 3.24 & 3.24 & 2.02 & 3.24 & 3.24 & 2.02 \\
\hline Corn gluten meal $(62 \%)$ & 3.74 & 3.74 & 3.00 & 3.74 & 3.74 & 3.00 \\
\hline DL-Methionine & 0.33 & 0.33 & 0.33 & 0.33 & 0.33 & 0.33 \\
\hline L-Lysine HCL & 0.47 & 0.47 & 0.47 & 0.47 & 0.47 & 0.47 \\
\hline L-Threonine & 0.13 & 0.13 & 0.13 & 0.13 & 0.13 & 0.13 \\
\hline Mono calcium phosphate & 0.75 & 0.75 & 0.75 & 0.75 & 0.75 & 0.75 \\
\hline Lime stone & 1.58 & 1.58 & 1.58 & 1.58 & 1.58 & 1.58 \\
\hline Salt & 0.23 & 0.23 & 0.23 & 0.23 & 0.23 & 0.23 \\
\hline Sodium bicarbonate & 0.20 & 0.20 & 0.20 & 0.20 & 0.20 & 0.20 \\
\hline Choline Chloride (60\%) & 0.05 & 0.05 & 0.05 & 0.05 & 0.05 & 0.05 \\
\hline Premix $^{1}$ & 0.30 & 0.30 & 0.30 & 0.30 & 0.30 & 0.30 \\
\hline Total & 100.00 & 100.00 & 100.00 & 100.00 & 100.00 & 100.00 \\
\hline \multicolumn{7}{|c|}{ Calculated chemical composition $(\%)$} \\
\hline Crude Protein (\%) & 17.00 & 17.00 & 15.73 & 17.00 & 17.00 & 15.73 \\
\hline Metabolisable Energy (Kcal/kg) & 2850.00 & 2850.00 & 2850.00 & 2850.00 & 2850.00 & 2850.00 \\
\hline Calcium $(\%)$ & 3.73 & 3.73 & 3.73 & 3.73 & 3.73 & 3.73 \\
\hline Phosphorus (total) (\%) & 0.55 & 0.55 & 0.55 & 0.55 & 0.55 & 0.55 \\
\hline Available Phosphorus (\%) & 0.38 & 0.38 & 0.38 & 0.38 & 0.38 & 0.38 \\
\hline Methionine \% & 0.40 & 0.40 & 0.40 & 0.40 & 0.40 & 0.40 \\
\hline Lysine $\%$ & 0.80 & 0.80 & 0.80 & 0.80 & 0.80 & 0.80 \\
\hline Threonine $\%$ & 0.55 & 0.55 & 0.55 & 0.55 & 0.55 & 0.55 \\
\hline Sodium $\%$ & 0.16 & 0.16 & 0.16 & 0.16 & 0.16 & 0.16 \\
\hline Chlorine $\%$ & 0.16 & 0.16 & 0.16 & 0.16 & 0.16 & 0.16 \\
\hline \multicolumn{7}{|l|}{ Feed Additives: } \\
\hline Protease (kg/ton feed) & 0.00 & 0.05 & 0.05 & 0.00 & 0.05 & 0.05 \\
\hline Probiotic (kg/ton feed) & 0.00 & 0.00 & 0.00 & 0.05 & 0.05 & 0.05 \\
\hline
\end{tabular}

${ }^{1}$ Each one kg of premix contains: Vitamin A (IU) 3,333,333; Vitamin D3 (IU) 666,667; Vitamin E, (IU) 3,333; Vitamin K3 (mg) 667; Thiamin (mg) 333; Riboflavin, (mg) 1,667; Niacin (mg) 10,000; Pantothenic acid (mg) 3,667; Pyridoxine (mg) 500; Biotin (mg) 17; Folic acid (mg) 333; Cyanocoblamin (mg) 3; Manganese (mg) 20,000; Zinc (mg) 16,667; Copper, (mg) 1,333; Selenium (mg) 33; Iron, (mg) 10,000; Iodine, (mg) 333; Cobalt (mg) 33.33333; Choline (mg) 200000; Calcium Carbonate (Carrier) up to $1 \mathrm{~kg}$. 
Table 2: Effect of probiotic and/or protease enzyme on some production parameters in commercial layers. (Mean \pm SEM)

\begin{tabular}{|c|c|c|c|c|c|c|}
\hline \multirow[b]{2}{*}{ Parameter } & \multicolumn{6}{|c|}{ Group } \\
\hline & 1 & 2 & 3 & 4 & 5 & 6 \\
\hline FI $(g / h / d)$ & $110.67 \pm 3.76^{\mathrm{a}}$ & $111.35 \pm 5.37^{\mathrm{a}}$ & $112.57 \pm 6.75^{\mathrm{a}}$ & $110.59 \pm 4.32^{\mathrm{a}}$ & $111.75 \pm 5.96^{\mathrm{a}}$ & $111.48 \pm 7.44^{\mathrm{a}}$ \\
\hline $\begin{array}{l}\text { ELR } \\
(\% / h / d)\end{array}$ & $84.49 \pm 2.33^{b}$ & $89.85 \pm 1.15^{\mathrm{a}}$ & $85.12 \pm 1.86^{b}$ & $89.67 \pm 1.10^{\mathrm{a}}$ & $91.21 \pm 1.41^{\mathrm{a}}$ & $89.92 \pm 2.18^{a}$ \\
\hline $\operatorname{AEW}(g)$ & $62.30 \pm 2.45^{\mathrm{b}}$ & $64.08 \pm 3.45^{\mathrm{a}}$ & $62.10 \pm 2.85^{b}$ & $64.33 \pm 3.71^{\mathrm{a}}$ & $64.57 \pm 2.56^{\mathrm{a}}$ & $64.13 \pm 2.15^{a}$ \\
\hline FCE & $2.10 \pm 0.11^{b}$ & $1.93 \pm 0.08^{a}$ & $2.13 \pm 0.14^{b}$ & $1.92 \pm 0.07^{\mathrm{a}}$ & $1.90 \pm 0.08^{\mathrm{a}}$ & $1.93 \pm 0.13^{\mathrm{a}}$ \\
\hline
\end{tabular}

Table 3: Effect of probiotic and/or protease enzyme on some biochemical parameters in commercial layers. $($ Mean \pm SEM)

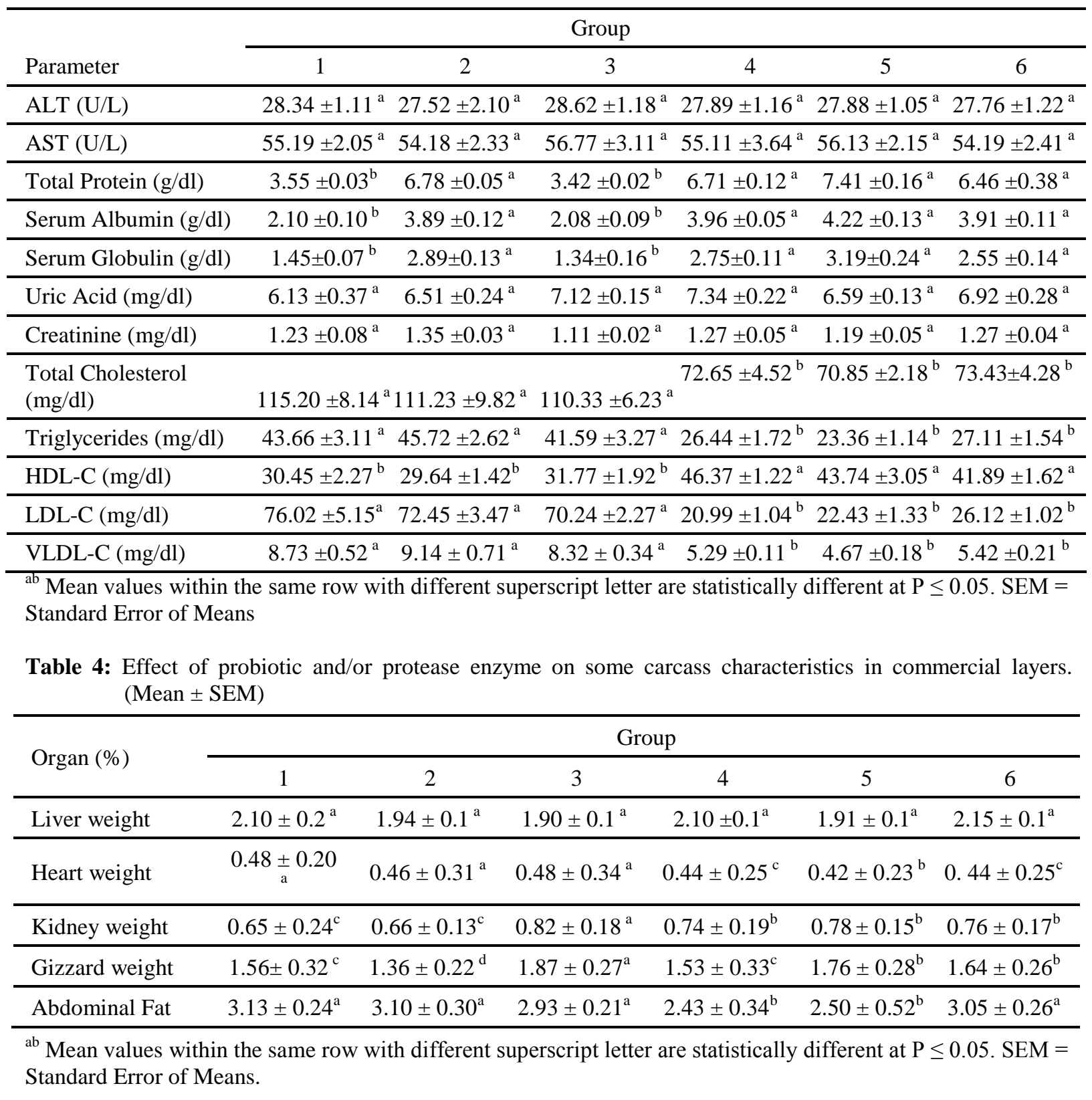


Table 5: Effect of probiotic and/or protease enzyme on Sensory attributes of salted cooked chicken meat in commercial layers. (Mean \pm SEM)

\begin{tabular}{|c|c|c|c|c|c|c|}
\hline \multirow{2}{*}{ Descriptor } & \multicolumn{6}{|c|}{ Group } \\
\hline & 1 & 2 & 3 & 4 & 5 & 6 \\
\hline Appearance & $6.10 \pm 0.02^{\mathrm{d}}$ & $6.23 \pm 0.02^{\mathrm{bc}}$ & $6.18 \pm 0.02^{c}$ & $6.27 \pm 0.02^{b}$ & $6.34 \pm 0.03^{a}$ & $6.15 \pm 0.01^{\mathrm{cd}}$ \\
\hline Juiciness & $4.89 \pm 0.02^{d}$ & $5.11 \pm 0.02^{b}$ & $5.03 \pm 0.04^{\mathrm{c}}$ & $5.14 \pm 0.03^{b}$ & $5.34 \pm 0.03^{\mathrm{a}}$ & $5.01 \pm 0.02^{c}$ \\
\hline Tenderness & $4.58 \pm 0.26^{\mathrm{b}}$ & $5.42 \pm 0.26^{\mathrm{a}}$ & $4.90 \pm 0.27^{b}$ & $5.45 \pm 0.32^{\mathrm{a}}$ & $5.63 \pm 0.30^{\mathrm{a}}$ & $4.98 \pm 0.16^{\mathrm{b}}$ \\
\hline Flavor & $4.50 \pm 0.27^{b}$ & $5.62 \pm 0.26^{\mathrm{a}}$ & $5.54 \pm 0.22^{a}$ & $5.64 \pm 0.33^{\mathrm{a}}$ & $5.73 \pm 0.21^{\mathrm{a}}$ & $5.32 \pm 0.30^{\mathrm{a}}$ \\
\hline Acceptability* & $6.11 \pm 0.03^{\mathrm{d}}$ & $6.39 \pm 0.04^{\mathrm{b}}$ & $6.35 \pm 0.04^{b}$ & $6.54 \pm 0.03^{\mathrm{a}}$ & $6.60 \pm 0.05^{\mathrm{a}}$ & $6.22 \pm 0.03^{c}$ \\
\hline \multicolumn{7}{|c|}{$\begin{array}{l}\text { ab Mean values within the same row with different superscript letter are statistically different at } P \leq 0.05 \text {. SEM }= \\
\text { Standard Error of Means. *Acceptability =Overall acceptability. 1-Yellowish Meat Color Intensity: Extremely } \\
\text { light (1), very light (2), slightly light (3), moderate intense (4), slightly intense (5), very intense }(6) \text { and } \\
\text { extremely intense (7). 2-Juiciness: Extremely dry (1), very dry (2), slightly dry (3), moderate juicy (4), slightly } \\
\text { juicy (5), very juicy (6) and extremely juicy (7). 3-Tenderness: Extremely tender (1), very tender (2), slightly } \\
\text { tender (3), moderate tough (4), slightly tough (5), very tough (6) and extremely tough (7). 4-Chicken Flavor } \\
\text { Intensity: Extremely weak (1), very weak (2), slightly weak (3), moderate intense (4), slightly intense (5), very } \\
\text { intense (6) and extremely intense (7). 5-Overall Acceptability of Meat: Extremely unacceptable (1), very } \\
\text { unacceptable (2), slightly unacceptable (3), moderate acceptable (4), slightly acceptable (5), very acceptable (6) } \\
\text { and extremely acceptable (7) (Snedecor and Cochran, 1987). }\end{array}$} \\
\hline
\end{tabular}

\section{DISCUSSION}

The birds fed rations with normal crude protein content $(17 \%)$ and treated with protease enzyme (group 2) or treated with probiotic (group 4) or treated with a combination of probiotic and protease (group 5) and birds fed ration low in crude protein content $(15.73 \%)$ with a combination of probiotic and protease enzyme (group 6) showed a significant increase of production parameters (egg laying rate, average egg weight and feed conversion per eggs) when compared with the control group. These may be attributed to the improvement effect of protease enzyme on protein digestion and utilization (Cowieson and Adeola, 2005) and gut microbial balance by substrate reduction (Romero et al., 2013). In addition, Probiotic can also support healthy performance although, unlike enzymes, their mode of action is to establish and maintain a beneficial microbial population in the gut of the birds. This leads to health gut that has a positive impact on birds' nutrient utilization and consequently birds' performance (Lee et al., 2010).

These findings are in agreement with that obtained by Raka et al. (2014) who reported that, supplementation of layers with liquid probiotics leads to the highest hen day production and egg weight. In addition, Saadia and Soliman (2010) indicated that a significant higher egg production was recorded in Hy-line layers supplemented with probiotic Saccharomyces cerevisiae. On the other hand, Daneshyar et al. (2009) reported that the addition of probiotics did not have significant effect on egg production and egg mass but significant effect was recorded on egg weight. The same result was reported by Ramasamy et al. (2010) who reported that supplementation of hens with Lactobacillus cultures did not influence the egg production or egg weight.

The inclusion of protease enzyme into commercial layers' feeds allows poultry producers to use feeds formulated with protein or amino acids that are $7.5 \%$ lower than the recommended standard with no sacrifice effect on animal production parameters (egg laying rate, average egg weight and feed conversion per eggs). This was evident in this study in group 3 . These may be attributed to the improvement effect of protease enzyme on protein digestion by hydrolysis of storage and structural proteins, and disrupts interactions of proteins with starch and fiber in the diet (Cowieson and Adeola, 2005). In addition, protease enzyme targets other anti-nutritional factors in the diet as residual trypsin inhibitors (Caine et al., 1998) and lectins in soybean meal and some other vegetable proteins that improving protein digestibility (Yu et al., 2007). Furthermore, protease enzymes improved body weight (Peek et al., 2009), feed efficiency, and digestibility of fat, protein (Freitas et al., 2011), and amino acids (Angel et al., 2011).

These results are consistent with those cited by Filho et al. (2015) who concluded that, supplementation of diets low in nutrients with $500 \mathrm{~g}$ per ton of protease $(100 \mathrm{U} / \mathrm{g})$, provides egg production and feed conversion rates similar to those obtained in laying hens fed diet with the nutritional level recommended for the breed. 
Our findings for biochemical parameters revealed that, there were no effects of phytase enzyme and probiotic either in single or in a combination form on liver (ALT and AST) and kidney (uric acid and creatinine) functions. The birds fed ration with normal crude protein $(17 \%)$ and treated with protease enzyme (group 2) and probiotic treated groups (group 4, 5 and 6) showed a significant increase of serum total protein, albumin and globulin when compared with birds fed basal diet. These findings may be attributed to the improvement effects of protease enzyme and probiotic in the intestinal environment which leading to improvement of the digestion and absorption of the nutrients. In addition, the probiotic limits the damage caused by the pathogenic microorganisms therefore, it may increase the bioavailability of essential nutrients. These results are in agreement with Khodary et al. (2004) and Farag et al. (2009).

Regarding the lipid profile, probiotic treated groups 4, 5 and 6 showed a significant decrease of serum total cholesterol, TG, LDL-C and VLDL-C when compared with other groups. In contrast, these groups showed a significant $(\mathrm{P} \leq 0.05)$ increase of HDL-C when compared with other groups. These findings could be attributed to reduced absorption or synthesis of cholesterol in the gastro-intestinal tract by probiotic supplementation (Ghiyasi et al., 2008). Probiotic microorganisms inhibit hydroxymthylglutaryl-coenzyme A, an enzyme involved in the cholesterol synthesis (Fukashima and Nakano, 1995). The most important mechanism by which probiotic eliminates cholesterol would likely be through reducing lipid absorption in intestine by binding bile acids, which results in increased cholesterol elimination and hepatic synthesis of new bile acid (Zhang et al., 2003 and Taherpour et al., 2009). These findings are in harmony with those obtained by Ashayerizadeh et al. (2011) who reported that, dietary supplementation with probiotic decrease cholesterol concentration when compared with birds fed basal diet, prebiotic and antibiotic diets. Mansoub (2010) reported that the cholesterol level of serum significantly was decreased in the groups supplemented with probiotics. The protease treated groups 2 and 3 did not show any significant differences in serum lipid profile when compared with the control group. These results are in harmony with those obtained by El-Katcha et al. (2014) who found that, addition of protease enzymes for broilers feeds has no significant effect on serum lipid profile.

Regarding the carcass quality, the obtained results revealed that, feeding layers with probiotics had no statistically significant effect on some internal organs include gizzard, and liver. These results were in agreement with those obtained by Sojoudi et al. (2012). They measured the effect of different levels of probiotics on carcass traits of chickens and results revealed that probiotics had no statistically significant effect on some carcass traits. They concluded that using probiotic is recommendable from nutrition aspects because it had significant effect on some carcass traits including back neck chine weight, gizzard weight and liver weight and even about characteristics which had no statistically significant effect on them, often improved them as numeral. Khalaji et al. (2012) also studied the effects of probiotic on chicken broilers and the results revealed that there is no difference between probiotic treated birds in carcass and gizzard characteristics.

The abdominal fat percentage in groups 4 and 5 were lower than those of the other groups. These results were in agreement with those of Mandai et al. (1994), Islam et al. (2004), and Ignatova et al. (2009). On the other hand, our results were disagreed with those obtained by Ayasan and Okan (2001) who investigated the effect of four levels of probiotic on fattening performance and carcass characteristics of Japanese quails. The results showed that the carcass characteristics were not affected by the probiotic supplementation. Also, Ignatova et al. (2009) found no significant differences in the carcass yield among the control and probiotic experimental groups. In addition, Mandai et al. (1994) found that probiotics feeding did not have any influence on the carcass yield. Islam et al. (2004) found that supplementation of probiotics had no effect on the weight of internal organs.

The obtained results revealed that, groups 2, 4 and 5 received the highest grade for breast meat juiciness and tenderness than those of groups 1,3 and 6 . Similarly, for overall acceptability parameter, layers breast muscle sample from groups 2, 4, 5 and 6 were significantly higher than samples of groups 1 and 3 . These results were similar to those obtained by Pelicano et al. (2003). They evaluated the effect of probiotics on carcass and meat quality of broilers and reported that in the sensory analysis, meat flavor and general aspect 72 hours after slaughter were better when probiotics were added in both water and diet. Sensory analyses of cooked chicken meat have improved juiciness and tenderness in the group receiving the probiotic concurrently with protease enzyme. Probiotic use in layers' feeds have been shown to provide a better taste, improved cooking characteristics and safer and healthier for the consumer.

It could be inferred that; the combination of protease and probiotic allows poultry producers to use feeds formulated with protein and amino acids that are 7.5\% lower than recommended industry standards. This combination not only with no sacrifice effect on animal performance but also with higher quantity and quality animal performance. Therefore, this combination is a potential to increase the producers profit. 


\section{REFERENCES}

Angel, C.R.; Saylor, W.; Vieira, S.L. and Ward, N. (2011): Effects of a mono-component protease on performance and protein utilization in 7- to 22-day-old broiler chickens. Poultry Science, 90: 2281-2286.

Ashayerizadeh, A.; Dabiri, N.; Ashayerizadeh, O.; Mirzadeh, K.H.; Roshanfekr, H. and Mamooee, M. (2009): Effect of dietary antibiotic, probiotic and prebiotic as growth promoters, on growth performance, carcass characteristics and hematological indices of broiler chickens. Journal of Biological sciences, 12 (1): 52-57.

Ashayerizadeh, A.; Dabiri, N.; Mirzadeh, K.H. and Ghorbani, M.R. (2011): Effect of dietary supplementation of probiotic and prebiotic on growth indices and serum biochemical parameters of broiler chickens. Journal of Cell and Animal Biology, 5 (8): 152-156.

Awad, W.A.; Ghareeb, K.; Abdel-Raheem, S. and Böhm, J. (2009): Effects of dietary inclusion of probiotic and synbiotic on growth performance, organ weights, and intestinal histomorphology of broiler chickens. Poult Sci., 88(1): 49-56.

Ayasan, T. and Okan, F. (2001): The effect of a diet with different probiotic (Protexin) levels on the fattening performance and carcass characteristics of Japanese Quails. Proceedings of XVth European Symposium on the Quality of Poultry Meat, Kupadasi, Turkey, pp169174.

Bansal, G.R.; Singh, V.P. and Sachan, N. (2011): Effect of probiotic supplementation on the performance of broilers. Asian J. Anim. Sci., 5: 277-284.

Caine, W.R.; Verstegen, M.W.A.; Sauer, W.C.; Tamminga, S. and Schulze, H. (1998): Effect of protease treatment of soybean meal on content of total soluble matter and crude protein levels of soybean trypsin inhibitors. Animal Feed Science and Technology, 71: 177-183.

Chichlowski, M.; Croom, J.; McBride, B.W.; Havenstein, G.B. and Koci, M.D. (2007): Metabolic and physiological impact of probiotics or direct-fed-microbials on poultry: A brief review of current knowledge. Int. J. Poult.Sci., 6(10): 694-704.

Commission of the European Communities (2003): "Regulation of the European parliament and of the council on additives for use in animal nutrition."

Cowieson, A.J. and Adeola, O. (2005): Carbohydrases, proteases and phytase have an additive effect in nutritionally marginal diets for broiler chicks. Poultry Science, 84: 18601867.

Daneshyar, M.; Kermanshahi, H. and Golian, A. (2009): Changes of biochemical parameters and enzyme activities in broiler chickens with cold-induced ascites. Poultry Science, 88(1): 106-10.

Dhama, K. and Singh, S.D. (2010): Probiotics improving poultry health and production: an overview. Poultry Punch, 26 (3): 41.

Domas, B.L. (1975): Colorimetric determination of total protein. Clin. Chem., 21 (1): 159-166.

Doumas, B. (1971): Colorimetric method for albumin determination. Clin. Chim. Acta, 31: 87-92.

Duncan, D.B. (1955): Multiple range and multiple F tests. Biometrics, 11:1-42.

El-Katcha, Mohamed I.; Mosaad A. Soltan; Hany F. El-Kaney and El-Sayed R. Karwarie (2014): Growth Performance, Blood Parameters, Immune response and Carcass Traits of Broiler Chicks Fed on Graded Levels of Wheat Instead of Corn Without or With Enzyme Supplementation. Alexandria Journal of Veterinary Sciences, 40: 95-111.

Farag, E.A.; Ali, M. Ali; Seddiek Sh. A. and Sabry, E.O. (2009): Comparative Efficacy of Prebiotic Mannan-Oligosaccharide And Diclazuril In Chickens Experimentally Infected With Eimeria tenella. Zag. Vet. J. (ISSN. 1110-1458) 37 (5):102 -115.

Filho, Javer Alves Vieira; Adriano Geraldo; Luiz Carlos Machado; Jerônimo Ávito de Brito; Antônio Gilberto Bertechini and Elise Saori Floriano Murakami (2015): Effect of protease supplementation on production performance of laying hens. Acta Scientiarum. Animal Sciences, 37(1):29-33.

Flegg, HM. (1973): Quantitative-enzymaticcolourimetric determination of total cholesterol and HDL-C in serum or plasma. Ann Clin Biochem, 10:79-88.

Freitas, D.M.; Vieira, S.L.; Angel, C.R.; Favero, A. and Maiorka, A. (2011): Performance and nutrient utilization of broilers fed diets supplemented with a novel mono-component protease. J. Appl. Poult. Res., 20: 322-334.

Friedewald, W.T.; Levy, R.I. and Fredrickson, D.S. (1972): Estimation of the concentration of LDL cholesterol in plasma, without use of the preparative ultracentrifuge. Clin. Chem., 18: 499-502.

Fukashima, M. and Nakano, M. (1995): The effect of probiotic on faecal and liver lipid classes in rats. Brit. J. Nutr., 73: 701-710.

Fuller, R. (Ed.) (1992): Probiotics. The Scientific Basis. Chapman and Hall, London.

Ghiyasi, M.; Rezaei, M. and Sayyahzadeh, H. (2008): Effect of prebiotic (fermacto) in low protein diet on performance and carcass characteristics of broiler chicks. Int. J. Poultry Sci., 6: 661665. 
Gordon, T.; Castelli, W.P.; Hjortland, M.C.; Kannel, W.B. and Dawber, T.R. (1977): High density lipoprotein as protective factor against coronary heart disease: The Framingham study. Am. J. Med., 62: 707-714.

Haisman, P. and Muller, B.P. (1977): Glossary of clinical chemistry and terms. Butter worth, London, P126.

Henry, R.J. (1974): Clinical chemistry, principles and techniques. Second Ed., Harper and Raw, 525531.

Ignatova, M.; Sredkova, $V$. and Marasheva, $V$. (2009): Effect of dietary inclusion of probiotic on chickens performance and some blood indices. Biotechnology in Animal Husbandry, 25 (5-6): 1079-1085.

Islam, M.W.; Rahman, M.M.; Kabir, S.M.L.; Kamruzzaman, S.M. and Islam, M.N. (2004): Effects of probiotics supplementation on growth performance and certain haematobiochemical parameters in broiler chickens. Bangladesh Journal Veterinary Medicine, 2 (1): 39-43.

Khalaji, S.; Zaghari, M. and Nezafati, S. (2012): Proceeding of 4th Congress on Animal Science, 207-209.

Khodary, R.M.; Rezk, H.I. and Assaf, I.M.M. (2004): Comparative study on enramycin, probiotic and prebiotic as growth promoters in quails. The 7th Vet. Med. Zag. Conference Sharm El Sheikh, 699-710

Lee, K.; Lillehoj, H.S. and Siragusa, G.R. (2010): Direct-fed microbials and their impact on the intestinal microflora and immune system of chickens. Journal of Poultry Science, 47: 106114.

Lee, S.; Lillehoj, H.S.; Park, D.W.; Hong, Y.H. and Lin, J.J. (2007): Effects of Pediococcus and Saccharomyces-based probiotic (MitoMax) on coccidiosis in broiler chickens. Comp. Immunol. Microbiol. Infect. Dis., 30(4): 261268.

Lemme, A.; Ravindran, V. and Bryden, W.L. (2004): Ileal digestibility of amino acids in feed ingredients for broilers. World's Poult. Sci. J., 60: 423-437.

Mandai, S.K.; Biswas, I.K. and Mandal, L. (1994): Efficiency of different growth promoters on the performance of boilers. Indian Journal of Poultry science, 92: 13-17.

Mansoub, N.H. (2010): Effect of Probiotic Bacteria Utilization on Serum Cholesterol and Triglycrides Contents and Performance of Broiler Chickens. Global Veterinaria, 5(3): 184-186.

Odunsi, A.A.; Adegbile, S.A.; Akande, T.O. and Olayeni, T.B. (2009): Neem (Azadirachta indica) Seed Cake in the Diets of Cockerel Chickens. International Journal of Poultry Science, 8 (1): 47-51.
Peek, H.W.; van der Klis, J.D.; Vermulen, B. and Landman, W.J.M. (2009): Dietary protease can alleviate negative effects of a coccidiosis infection on production performance in broiler chickens. Anim. Feed Sci. Technol., 150:151159.

Pelicano, E.R.L.; Souza, P.A.; Souza, H.B.A.; Oba, A.; Norkus, E.A.; Kodawara, L.M. and Lima, T.M.A. (2003): Effect of Different Probiotics on Broiler Carcass and Meat Quality. Braz. J. Poult. Sci., 3 (3): 207-214.

Raka Pambuka, S.; Sjofjan, O. and Eka Radiati, L. (2014): Effect of Liquid Probiotics Mixed Culture Supplements through Drinking Water on Laying Hens Performance and Yolk Cholesterol. Journal of World's Poultry Research, 4 (1): 05-09.

Ramasamy, K.; Abdullah, N.; Wong, MC.; Karuthan, C. and Ho, YW. (2010): Bile salt deconjugation and cholesterol removal from media by Lactobacillus strains used as probiotics in chickens. Journal of the Science of Food and Agriculture, 90 (1): 65-69.

Romero, L.F.; Parsons, C.M.; Utterback, P.L.; Plumstead, P.W. and Ravindran, V. (2013): Comparative effects of dietary carbohydrases without or with protease on the ileal digestibility of energy and amino acids and AMEn in young broilers. Animal Feed Science and Technology., 181 (1): 35-44.

Saadia, M.H. and Soliman, N.K. (2010): Effect of probiotic (Saccharomyces cerevisiae) adding to diets on intestinal microflora and performance of hy-line layers he ns. J. Am. Sci., 6 (11):159-169.

Snedecor, G.W. and Cochran, W.G. (1987): Statistical methods (7th Edn.). Ames, IA, USA: The Iowa State. University Press, pp: 221-222.

Snedecor, G.W. and Cochran, W.C. (1989): Statistical methods. The eighth. Edition, Iowa University Press, Ames, Iowa, USA.

Sojoudi, M.R.; Dadashbeiki, M. and Bouyeh, M. (2012): J. Basic. Appl. Sci. Res., 2: 67786794. SPSS Inc. Released (2009): PASW Statistics for Windows, Version 18.0. Chicago: SPSS Inc.

Taherpour, K.; Moravej, H.; Shivazad, M.; Adibmoradi, M. and Yakhchali, B. (2009): Effects of dietary probiotic, prebiotic and butyric acid glycerides on performance and serum composition in broiler chickens. Afr. J. Biotechnol., 8:2329-2334.

Tietz, N.W. (1976): Fundamentals of clinical chemistry. WB saunders Company. Washington D.C.

Varliy, H. (1974): Clinical chemistry methodology,past and present. Ann. Clin. Chem., 11: 161-63.

Yu, B.; Wu, S.T.; Liu, C.C.; Gauthier, R. and Chiou, P.W.S. (2007): Effects of enzyme inclusion in 
a maize-soybean diet on broiler performance. Animal Feed Science and Technology, 134:283-294.
Zhang, W.F.; Li, D.F.; Lu, W.Q. and Yi, G.F. (2003): Effect of isomalto-oligosaccharides on broiler performance and intestinal micro flora. Poultry Science, 82: 657-663.

\section{استخدام البروبيوتلك وإنزيم البروتيز في الاجاج البياض \\ على محمد محد أحد ، محي عثمان محد عبل الفتاح ، مجذي ثابت جرجس ، صبري السبا عمر}

Email: alimohamedphd@gmail.com Assiut University web-site: www.aun.edu.eg

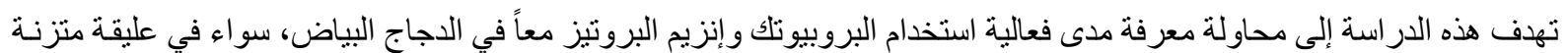

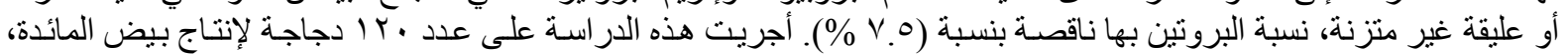

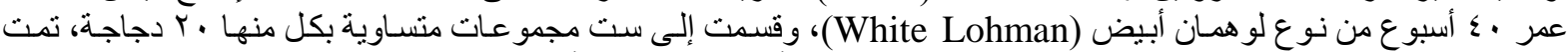

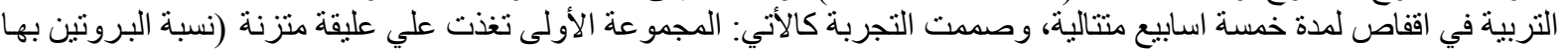

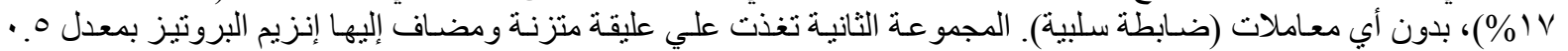

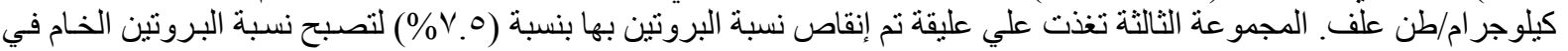

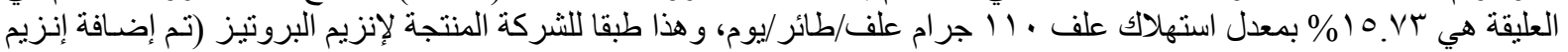

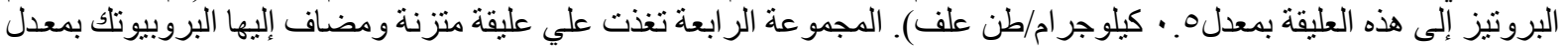

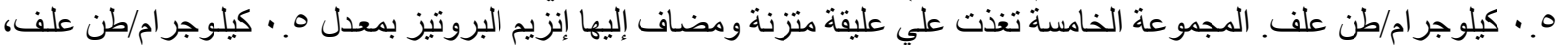

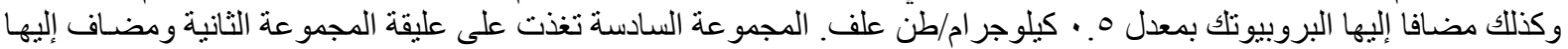

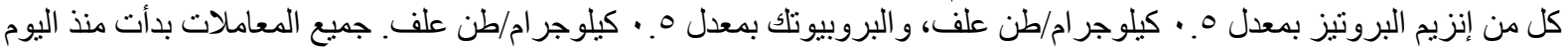

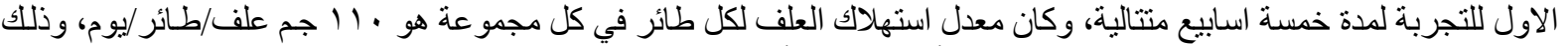

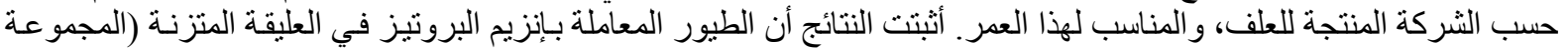

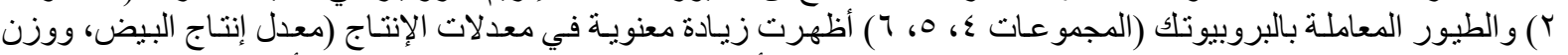

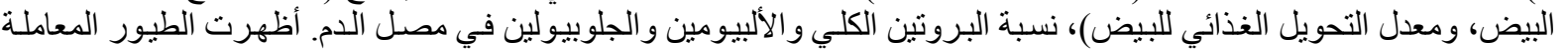

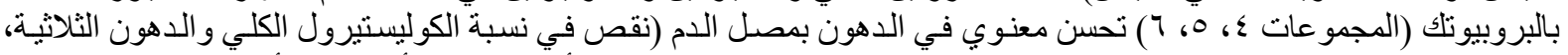

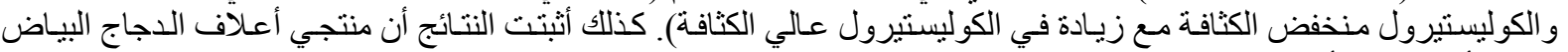

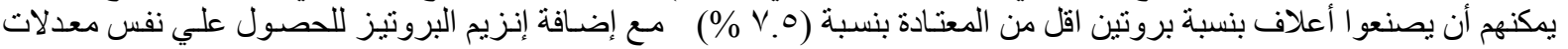

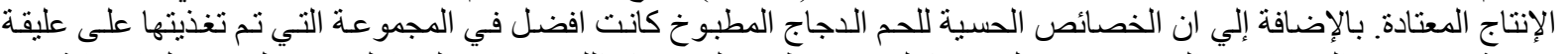

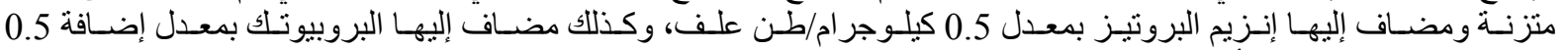

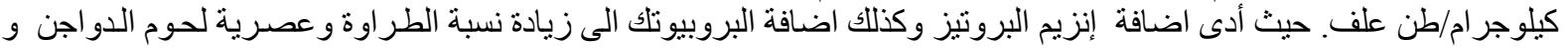

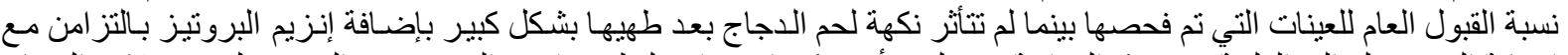

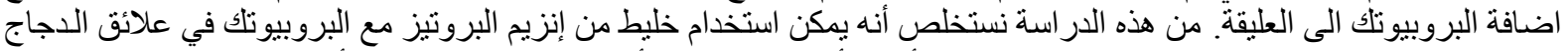
البياض ذات مستوى بروتين منخفض، وذللك لما له من أهمية أقتصادية دون التأثثر علي معدلات الإنتاج أو خصائص التص اللحن. 